\title{
Relationships between burned area, forest cover loss, and land cover change in the Brazilian Amazon based on satellite data
}

\author{
T. Fanin and G. R. van der Werf \\ Faculty of Earth and Life Sciences, Vrije Universiteit Amsterdam, Amsterdam, the Netherlands \\ Correspondence to: T. Fanin (t.fanin@vu.nl)
}

Received: 24 April 2015 - Published in Biogeosciences Discuss.: 3 June 2015

Revised: 23 September 2015 - Accepted: 29 September 2015 - Published: 22 October 2015

\begin{abstract}
Fires are used as a tool in the deforestation process. Yet, the relationship between fire and deforestation may vary temporally and spatially depending on the type of deforestation and climatic conditions. This study evaluates spatiotemporal dynamics of deforestation and fire represented by burned area over the 2002-2012 period in the Brazilian Legal Amazon. As a first step, we compared newly available Landsat-based maps of gross forest cover loss from the Global Forest Change (GFC) project with maps of deforestation extent from the Amazon Deforestation Monitoring Project (PRODES) produced by the Brazilian National Institute for Space Research (INPE). As a second step, we rescaled the Landsat-based data to the $500 \mathrm{~m}$ resolution of the Moderate Resolution Imaging Spectroradiometer (MODIS) burned area data (MCD64A1) and stratified this using MODIS land cover data to study the role of burned area in forest cover loss and deforestation. We found that while GFC forest cover loss and PRODES deforestation generally agreed on spatial and temporal dynamics, there were several key differences between the data sets. Both showed a decrease in the extent of forest cover loss or deforestation after 2004, but the drop was larger and more continuous in PRODES than in GFC. The observed decrease in forest cover loss or deforestation rates over our study period was mainly due to lower clearing rates in the evergreen broadleaf forests in the states of Mato Grosso, Pará, and Rondônia. GFC indicated anomalously high forest cover loss in the years 2007 and 2010, which was not reported by PRODES. The burned area data indicated that this was predominantly related to increased burned area occurring outside of the tropical forest area during these dry years, mainly in Pará. This indicated that fire and forest loss dynamics in woodlands or secondary forests may be equally important as deforestation in regulat-
\end{abstract}

ing atmospheric $\mathrm{CO}_{2}$ concentrations. In addition to the decrease in forest cover loss rates, we also found that postdeforestation fire use declined; burned area within 5 years after forest cover loss decreased from 54 to $39 \%$ during our study period.

\section{Introduction}

In the tropics, fires are regularly used as a cheap means to dispose of vegetative debris on deforested land for the purpose of agriculture or pasture, and to maintain an open landscape. Fire represents a major source of carbon emissions in the Amazon, especially in the southern fringe of the Amazon known as the arc of deforestation (Fearnside et al., 2009). Various factors contribute to relatively high rates of deforestation in this region, including available infrastructure and capital and relatively long dry seasons (Kirby et al., 2006). Fire susceptibility is influenced by factors such as deforestation, forest management, cultivation and reforestation (Osborne, 2000). Development of human infrastructure, including road construction, and the spread of residential settlements in general increase deforestation and fire activity in more remote regions (Nepstad et al., 2001; Malhi et al., 2009). In 2005, approximately $90 \%$ of the observed burning in the southeast of Rondônia and the northwest of Mato Grosso occurred in previously deforested areas, thereby demonstrating the link between fire and land use and land cover change (LULCC) processes (Lima et al., 2012).

The objectives of landowners partly govern the degree to which fire is used in the deforestation process. In general, three stages can be distinguished: logging, clearing, and maintenance. In tropical logging, by only harvesting selected 
trees, bulldozers create networks of forest roads, killing nonharvested trees and fragmenting the forest and its canopy (Johns et al., 1996). This practice increases the amount of dead wood in the understory and the likelihood of fires. The damaged canopy allows light and wind to penetrate, increasing desiccation (Holdsworth and Uhl, 1997; Cochrane and Laurance, 2008). If fires occur they can affect forest composition and structure. Recovery is diminished due to the impact of surface fires on seed availability (Van Nieuwstadt et al., 2001). For clearing, slash-and-burn is a very efficient technique to clear land intentionally for cattle or pasture (Tinker et al., 1996). To prepare the field, vegetation is cut and left on the ground to dry. At the end of the dry season this is subsequently burned. If biomass remains after the first fire, the remains are piled up and burned again, often until all biomass is removed. Once everything is cleared, planting can be done directly in the ashes. Forest edge biodiversity is impoverished by grass invasion due to repetitive burning in rapid agricultural expansion (Balch et al., 2009). Maintenance fires are used regularly to prevent trees from invading pastures after deforestation, to recycle nutrients, and to remove crop residues (van der Werf et al., 2009).

The vast scales of fire and deforestation have become increasingly evident as a result of developments in remote sensing and research that has used the continuously increasing data streams associated with this. Often these deforestation-focused studies have used NASA's Landsat data (Tucker et al., 2004), but coarser-scale Moderate Resolution Imaging Spectroradiometer (MODIS) data are also used for rapid identification of deforestation location areas and trends in dynamics (Morton et al., 2005). Landsatgenerated deforestation data sets allow for accurate quantification of the total area of deforestation (Broich et al., 2009). Now spanning a time frame of approximately 25 years, the Brazilian National Institute for Space Research (INPE) has created the Amazon Deforestation Monitoring Project (PRODES) to quantify deforestation rates in the Brazilian Legal Amazon (BLA) (INPE, 2014). Initially only available in a tabular format, digital maps were created using a new methodology based on the work of Shimabukuro et al. (1998) from 1997 onwards (Hansen et al., 2008). PRODES has been used in many studies to evaluate the effects of deforestation (e.g., Morton et al., 2006; Broadbent et al., 2008). Also using Landsat satellite imagery, the Global Forest Change (GFC) project has compiled a global forest cover loss data set at the same spatial resolution as PRODES with an annual time step for the period 2001-2013 (Hansen et al., 2013). The objectives of these two data sets diverge as PRODES only focuses on primary forest loss, while GFC includes forest changes in every type of vegetation greater than $5 \mathrm{~m}$ in height and is a global data set whereas PRODES only focuses on the BLA.

Fire has been used as part of the clearing process since the inauguration of the Trans-Amazonian Highway in 1970 (Fearnside, 2005). Different remotely sensed data sets allow the quantity and intensity of fires to be estimated. Active fire algorithms (e.g., Giglio et al., 2003) detect a fire at the time of satellite overpass, while burned area algorithms (e.g., Roy et al., 2008) use satellite time series of vegetation indices and other information to classify whether a pixel was burned or not. Burned area algorithms are less sensitive to cloud cover and smoke and are therefore more reliable for spatiotemporal studies allowing better analysis of spatial association between landscape attributes and burning events, while active fires are better for identifying smaller fires and yield nearreal-time information (Roy et al., 2008).

After the first fire following deforestation there is generally still too much biomass on the ground to enable agriculture or cattle grazing. Usually, repetitive burning is carried out to remove remaining biomass. The number of fires is thought to depend on the post-deforestation land use, with agriculture requiring more complete combustion than pastures. For example, in a previous modeling exercise, pasture combustion completeness was set between 50 and $90 \%$, while conversion to cropland may lead to $100 \%$ combustion completeness over a period of 1-3 years (Morton et al., 2008). The connection between these fires and deforestation is well established. For example, according to a study focusing on one Landsat 5 TM tile (231/67 in the WR-2 indexing system) at the border of Rondônia and Mato Grosso, $31 \%$ of the area burned in 2005 was deforested in one of the preceding 3 years (Lima et al., 2012).

Deforestation and forest cover loss rates are impacted by numerous socioeconomic factors, and via the firedeforestation link drought also plays a role in explaining spatiotemporal variability (van der Werf et al., 2008). In general, drier-than-normal dry seasons see increased fire activity (Chen et al., 2013), which can inhibit rainfall, creating a feedback mechanism (Nobre et al., 1991; Nepstad et al., 2001). In addition, the vulnerability of these forests may increase due to climate change (Aragão et al., 2008) with increased temperatures and stronger droughts (IPCC, 2007). In 2005, 2007, and 2010, three strong droughts occurred in the Amazon. Standardized anomalies of dry-season rainfall showed that $37 \%$ of the total area in 2005, and $57 \%$ in 2010, was experiencing rainfall more than 1 standard deviation below the long-term mean (Lewis et al., 2011). The 2005 event increased the number of fires observed by satellite-derived monthly and annual time series by $33 \%$ compared to the 1999-2005 mean (Aragão et al., 2007). Droughts are associated with the El Niño-Southern Oscillation, but they are also impacted by tropical Atlantic sea surface temperature (SST) anomalies related to the Atlantic Multidecadal Oscillation (AMO; Marengo et al., 2008). Eastern Amazonia is more vulnerable to fire during El Niño, whereas the south and southwest is more linked to AMO (Chen et al., 2011). Southern and eastern states in the Amazon Basin are relatively dry, with lower annual rainfall and stronger dry seasons, while the interior of the Amazon is more humid (Nepstad et al., 1994).

In this study we focus on the relationship between burned areas and forest cover loss using newly available data. We 
discuss and highlight the patterns seen in the forest cover loss, deforestation, and burned area data sets. Our main objective is to identify the role that fires play in these differences, and how droughts influence the fire-tree cover loss dynamics. We also focus on the spatial and temporal variability in the use of fire as a tool for deforestation for different states and land cover types.

\section{Data sets and methods}

Our study area is the Brazilian Legal Amazon, or BLA, which consists of nine Brazilian states in the northern part of Brazil (Fig. 1). Its geographic area is approximately 5 million $\mathrm{km}^{2}$. In total, $62 \%$ of the Amazon forest lies within Brazilian borders. It consists predominantly of closed tropical forest but also of cerrado (wooded savanna), agriculture, and pasture land (Carreiras et al., 2006). Deforestation is concentrated in the arc of deforestation along the southern and eastern edges of the BLA (Fearnside, 2005). We used four satellite-derived data sets characterizing forest dynamics and fire: GFC forest cover loss, PRODES deforestation, MODIS burned area, and MODIS land cover. After describing these data sets in more detail, we explain what steps we have taken to study relationships between the various data sets.

The PRODES deforestation data set is derived from Landsat data using algorithms described by Shimabukuro et al. (1998). Landsat TM bands 3, 4, and 5 are used to generate the fraction of vegetation, soil, and shade within each pixel using the constrained least-squares method. The image fraction is then classified using image segmentation followed by unsupervised image classification and image editing to determine primary forest deforestation (Valeriano et al., 2004). This methodology has been used since 1997, and once an area is detected as deforested, it is masked out and not considered anymore in following years.

GFC defines forest cover loss as a stand-replacement disturbance or the complete removal of tree cover canopy for the period 2001-2013. GFC uses pre-processed cloud-free Landsat images to calculate time-series spectral metrics. Over the study interval, three groups of per-band metrics were employed: reflectance values, mean reflectance and slope of linear regression of band reflectance value versus image date. Using these time-series metrics, a decision tree was used to find forest cover loss (Hansen et al., 2013). A key difference between GFC and PRODES is that PRODES only quantifies primary forest loss, while GFC includes changes in "all vegetation greater than $5 \mathrm{~m}$ in height". This may include the clearing of secondary forest or certain types of cultures such as palm oil production, and in general one expects that GFC flags more area than PRODES.

MODIS burned area (MCD64A1) is based on $500 \mathrm{~m}$ MODIS imagery coupled with $1 \mathrm{~km}$ MODIS active fire observations. It produces composite imagery to detect persistent changes and then uses spatial and temporal ac-

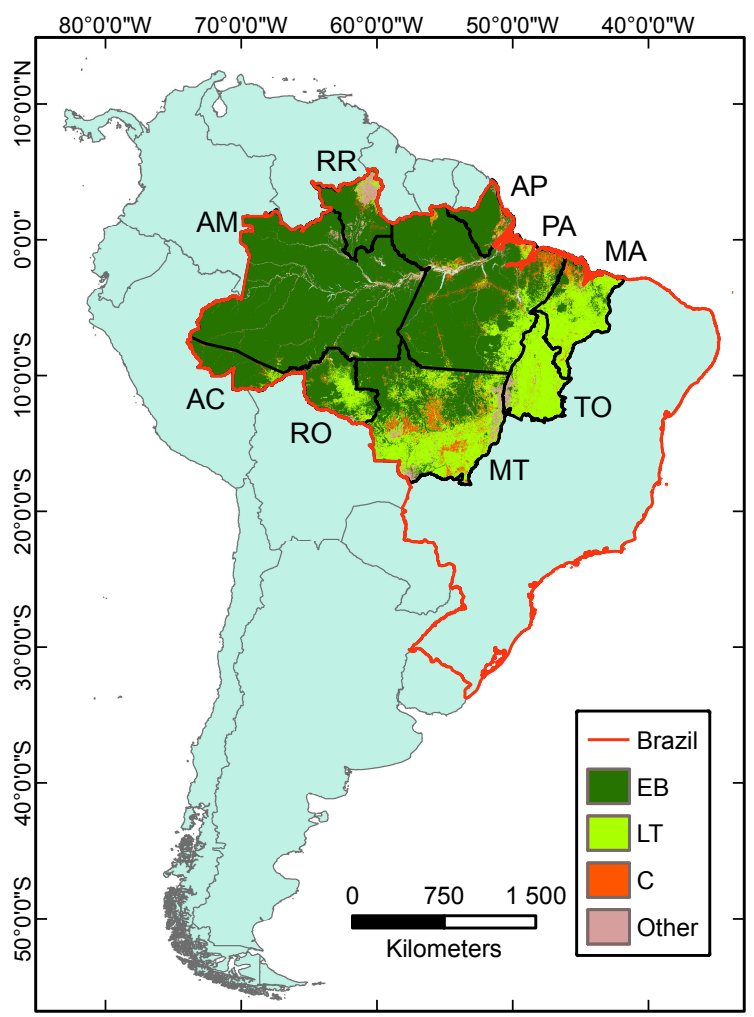

Figure 1. MODIS MCD12Q1 (v051) Land cover in the Brazilian Legal Amazon (BLA). EB: evergreen broadleaf forest; LT: low tree cover (shrubland and savannas); and C: cropland and cropland/natural vegetation mosaic. "Other" includes all remaining land cover such as grassland, needle leaf forest, permanent wetlands, or urban areas. Letter codes for the states in the BLA are as follows: AP, Amapá; PA, Pará; MA, Maranhão; TO, Tocantins; MT, Mato Grosso; RO, Rondônia; AC, Acre; AM, Amazonas; RR, Roraima.

tive fire information to create probabilistic thresholds to classify each pixel as burned or unburned (Giglio et al., 2009). To identify land cover changes, we used the MODIS MCD12Q1 land cover type product version 051 (Loveland and Belward, 1997; Friedl et al., 2010) with the International Geosphere-Biosphere Programme global land cover classification scheme.

To combine forest cover loss, burned area, and land cover data sets we used ArcMap10 to rescale PRODES and GFC to the $500 \mathrm{~m}$ MODIS grid using the most common $Z$ value. The rescaled data set slightly overestimated the area of forest loss in the BLA by approximately $4 \%$. However, this bias was uniform over time and space and did not change the general trend and patterns in which we are interested here. We performed all analyses at $500 \mathrm{~m}$ resolution and rescaled the results to $0.1^{\circ}$ to facilitate visual interpretation of the figures.

Because of the annual time step in the GFC and PRODES data, we have also merged the monthly burned area data into annual files to compare that layer with deforestation and forest cover loss. We have simplified the land cover classi- 
fication scheme to three classes with the dominant vegetation types in the BLA: evergreen broadleaf forest (EB), low tree cover (LT, which includes shrublands and savannas) and cropland $(\mathrm{C}$, including croplands interspersed with natural vegetation). Other land cover types, such as grassland, needle leaf forest or permanent wetland, have been merged (other) but excluded in our analyses as they only represent a very small portion of BLA land cover. We further analyzed the land use for each land cover group in the two states most affected by fires: Mato Grosso and Pará. We used the Landsatbased TerraClass land use data set from INPE, rescaled at $500 \mathrm{~m}$, available for 2008 and 2010 for this exercise (de Almeida et al., 2009).

Finally, we aimed to better understand not only how burned area and forest cover loss are related but also how frequently burned area is observed after land cover transition and whether this varies between post-tree-cover-loss land uses. For each evergreen broadleaf pixel where GFC indicated forest cover loss, we summed burned area occurrence during the 5 years following this event. This 5 -year time period was chosen to balance the number of years we had for analysis (which decreases when we lengthen our time period) and the time required for conversion. The 5-year time frame was also used by Lima et al. (2012), who showed that $15 \%$ of the fires in their study area in 2005 occurred in land deforested in 2000. Because our time series ended in 2012, we could only do this for 2002 through 2007. In the process, we kept track of the post-tree-cover-loss land use defined by the land cover type 5 years after tree cover loss. For each year of evergreen broadleaf forest cover loss, we calculated the fraction burned in the subsequent 5 years, and associated these fractions to evaluate potential trends in conversion and the role of fire in these trends. Finally, we stratified these summed fractions by post-forest-loss land cover type to evaluate potential trends in conversion and the use of fire in them.

\section{Results}

During our study period, within the BLA, both tree cover loss and burned areas were concentrated along the arc of deforestation (Fig. 2). The largest difference between GFC and PRODES on the one hand and burned area on the other is that forest loss and deforestation are concentrated along the edge of the Amazon forest, while most fire activity is observed further away from the deforestation frontier. In addition to the arc of deforestation, forest cover loss and deforestation occurs along the Amazon River and close to roads. A state-level breakdown shows that Mato Grosso (both GFC and PRODES indicate $33 \%$ of the total BLA loss), Pará (32\% for GFC, $36 \%$ for PRODES) and Rondônia $(12,13 \%)$ were the states with most forest cover loss over our full study period. There is spatial overlap between forest cover loss/deforestation and burned area, mainly in the southeast of Pará and in the east of Mato Grosso. However, regions with more shrubland or
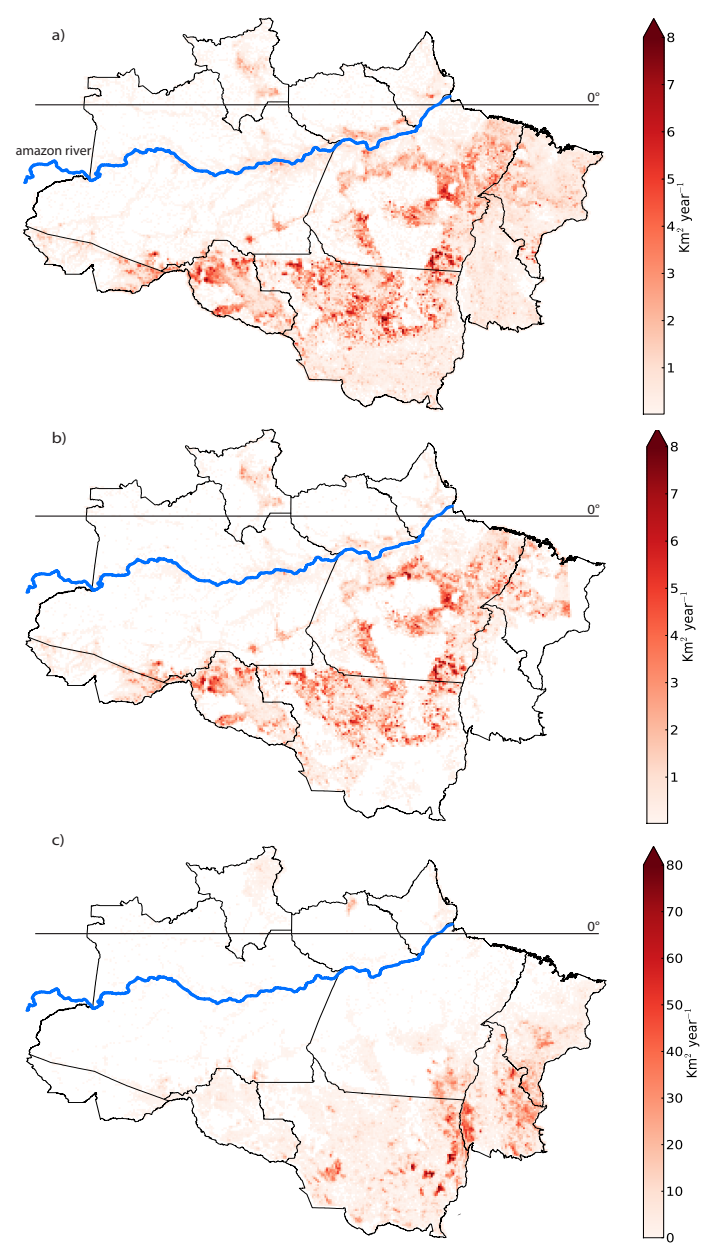

Figure 2. 2002-2012 mean forest loss (a, based on GFC), deforestation (b, based on PRODES), and burned area (c, based on MCD64A1). All data sets are regridded to $0.1^{\circ}$ resolution. Note the order-of-magnitude difference between forest loss and deforestation on the one hand and burned area on the other.

savannas, further away from the arc of deforestation (e.g., Tocantins and Maranhão), have the highest burned area.

Over our study period, PRODES and GFC annual forest cover loss increased up to the year 2004 and decreased afterwards (Fig. 3). While both data sets demonstrated this post2004 decline, the extent differed. PRODES showed a continuous decrease except for 2008 , while GFC plateaued towards the end of the study period at a higher level. In both data sets, all states showed a decrease between 2004 (highest year of deforestation during our study) and 2012. Mato Grosso, Pará, and Rondônia showed the largest reduction between 2004 and 2012 in both data sets, respectively 63, 50 and $56 \%$ in GFC and 94, 80 and $80 \%$ with PRODES. While all other states had a decrease of at least $40 \%$ according to PRODES, GFC does not show any other state having more than a $30 \%$ decrease. In addition, GFC has annual peaks in forest cover loss during dry years, especially in 2010, while PRODES does not show this variability in deforestation. 

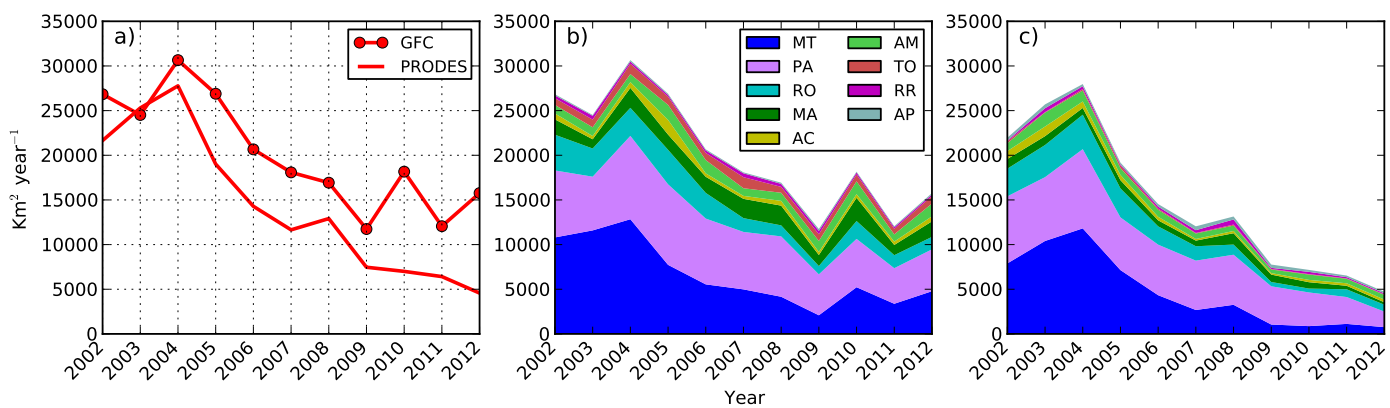

Figure 3. Annual forest loss estimates from the Global Forest Change (GFC) project and deforestation estimates from the Amazon Deforestation Monitoring Project (PRODES) for 2002-2012 in all of the BLA (a), and partitioned on state level for GFC (b) and PRODES (c).
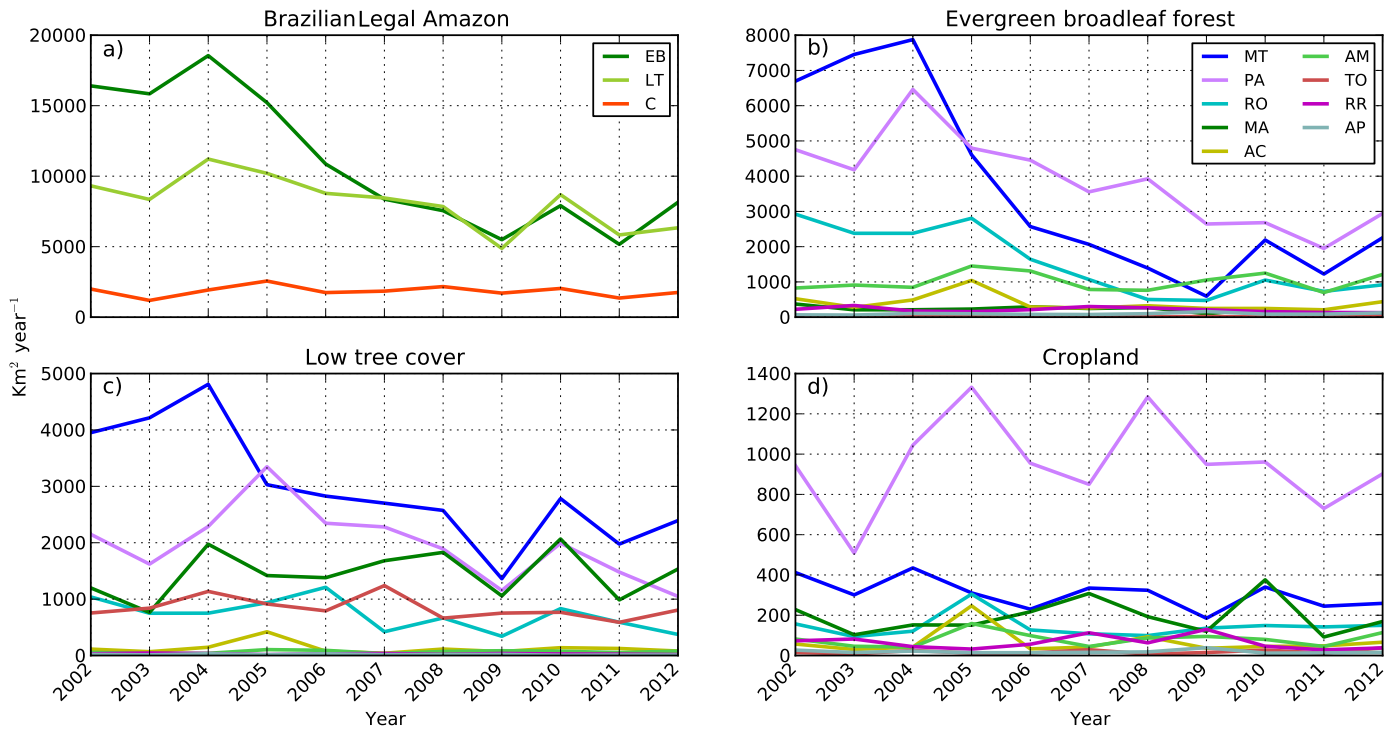

Figure 4. Annual state-level GFC forest loss for the Brazilian Legal Amazon and three land cover classes defined at the year of forest loss.

Partitioning GFC forest cover loss by land cover, we found that until 2006 most loss occurred in evergreen broadleaf forests (Fig. 4a). From 2002 to 2009, the amount of annual evergreen broadleaf forest loss dropped from approximately $16000 \mathrm{~km}^{2}$ to almost $5000 \mathrm{~km}^{2}$ and stayed relatively constant in the following years. The most significant decrease came again from Mato Grosso and Rondônia with an absolute forest cover loss reduction in evergreen broadleaf forests of 93 and $81 \%$, respectively (Fig. 4b). The decrease in forest cover loss started earlier in Mato Grosso (in 2004) than in Rondônia (in 2005) and was probably related to the strong 2005 drought, which was most prominent in the western BLA. The state with, on average, the second highest amount of forest cover loss, Pará, showed a slower diminution in evergreen broadleaf forest loss $(60 \%)$. Total loss in other types of land cover remained relatively stable during our study period (Fig. 4c-d). Mato Grosso is the only state with a significant decrease in clearing in the low-tree-cover biome, halving the amount of shrubland and savannas cleared between 2004 and 2012.
In contrast to these trends in deforestation and forest cover loss, total burned area remained relatively stable over our study period except in drier years, such as 2007 and 2010, when burned area increased markedly, especially in low tree vegetation. These peaks mainly occurred in southern and eastern states such as Mato Grosso, Pará, Maranhão, and Tocantins (Fig. 5a, b). In 2008, pastures as classified by TerraClass covered $15 \%$ of Mato Grosso's and $12 \%$ of Pará's surface. For a large part, pastures overlapped with our low-tree-cover class ( 80 and $65 \%$ of the pastures were in that class for those two states). In Mato Grosso, pasture fires represented only $7 \%$ of all burned area in 2008 and $9 \%$ in 2010 , while most of the burned area occurred in the "unmanaged land use" classes (86 and $87 \%$, respectively). In Pará, pasture fires comprised 19 and $34 \%$ of the burned area in 2008 and 2010 , also much lower than burned area in unmanaged areas (69 to $56 \%)$.

Focusing on burned area coinciding with GFC forest cover loss (so observed in the same grid cell in the same year), we found that these coinciding events occur mainly in ever- 

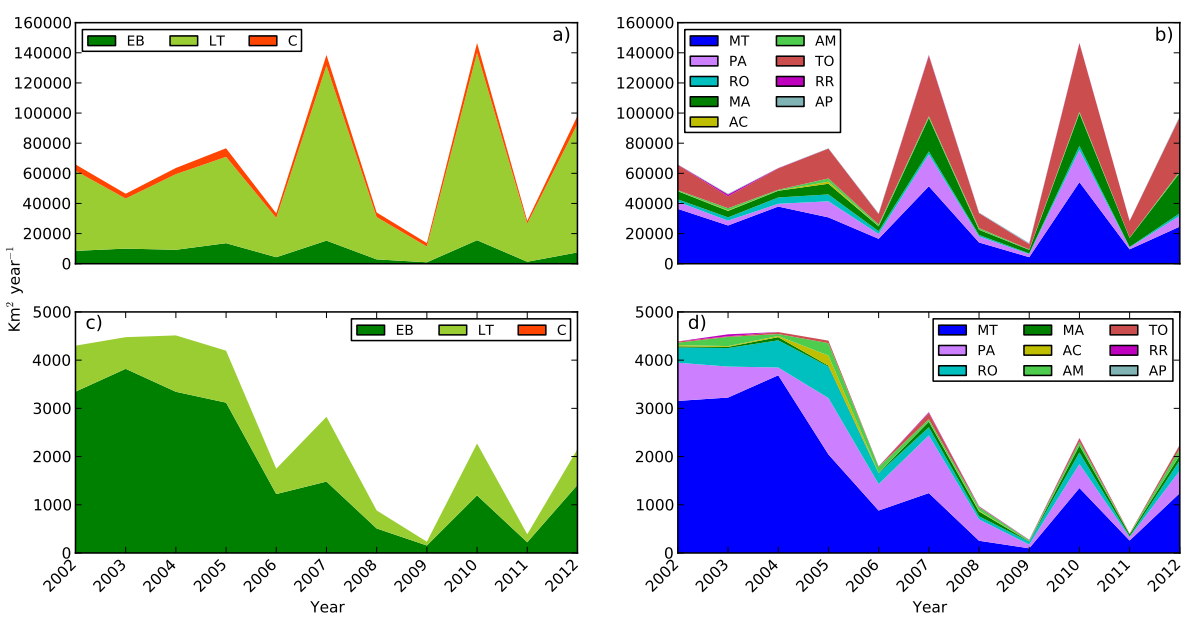

Figure 5. Burned area stratified by land cover $(\mathbf{a}, \mathbf{c})$ and by state $(\mathbf{b}, \mathbf{d})$. Top panels $(\mathbf{a}$ and $\mathbf{b})$ indicate total burned area; bottom panels show burned area coinciding with GFC forest loss.

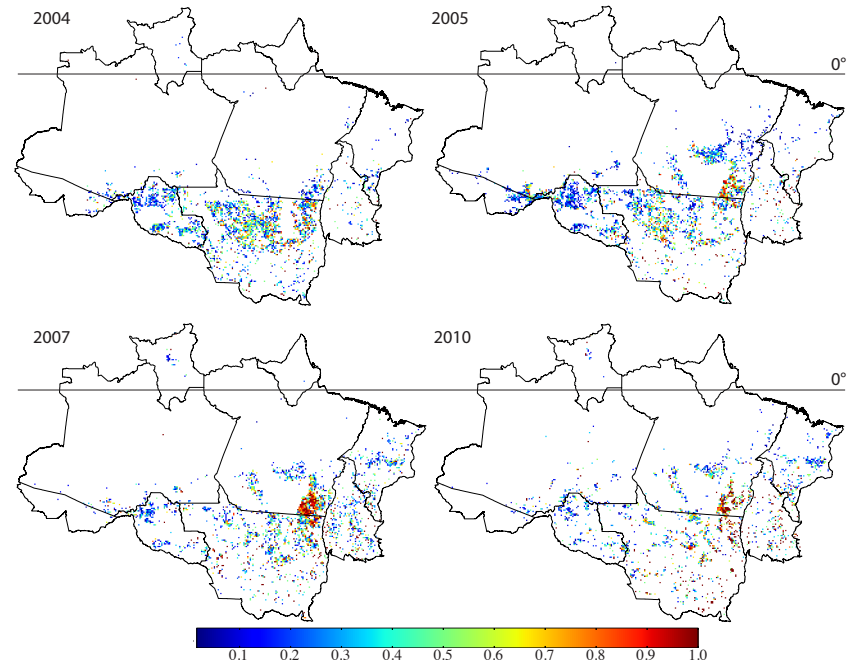

Figure 6. Fraction of GFC forest loss coinciding with burned area for the four highest fire and/or tree cover loss years in our study period, averaged at $0.1^{\circ}$ resolution.

green broadleaf forest and that this is only a small fraction of the total burned area in the BLA (Fig. 5c, d). The general trend is similar to total GFC, although the decrease starts after 2005 due to a drought in the southwest of the BLA, mainly in Acre and Amazonas. Looking into more detail at 4 years $(2004,2005,2007$, and 2010) with above-average tree cover loss and/or burned area, we found that the spatial distribution of coinciding forest cover loss and burning has changed (Fig. 6). Especially in 2004, but also in 2005, most of this was observed in northern Mato Grosso and Rondônia. These regions featured less prominently in the latter part of this analysis during the dry years of 2007 and 2010. In contrast, Pará had very little burned area in 2004 but started to have a major hotspot in the southeast in 2005 and in fol- lowing dry years. The central region of Pará had also more activity from 2005 onwards.

Using burned area and GFC to evaluate the time interval between forest cover loss and fire, we found that a substantial part ( $46 \%$ when averaged over the full study period) of cleared evergreen broadleaf forest was burned within 5 years after forest cover loss, with the use of fire decreasing over time. Of all forest loss grid cells, $24.5 \%$ was converted to shrubland or savannas, $18 \%$ was converted to cropland, and $3.5 \%$ had no permanent conversion (Fig. 7). We tested time periods from 2 to 6 years and found that shorter time periods lower this number somewhat (e.g., a period of 3 years yields $37 \%$ ), while longer time periods make a marginal difference. We also found that $10 \%$ of the land converted to shrubland or savanna was burned the same year as forest cover loss was detected in these grid cells (we could not identify whether it was the cause of conversion), while conversions to cropland were burned in the first year in about $7.5 \%$ of the grid cells. Grid cells identified as forest cover loss but remaining evergreen broadleaf forest had less than $2 \%$ burned areas.

Strikingly, when looking at the temporal trend of burned area after evergreen broadleaf GFC loss, we found that the use of fire after conversions to shrubland, savannas, or cropland decreased over our study period (Fig. 8). The fraction that burned for conversion to shrubland or savannas decreased from over $31 \%$ between 2002 and 2007 to $17 \%$ between 2007 and 2012. With all conversion types combined, post-tree-cover-loss burned area was most frequent for the grid cells that had forest loss in 2003 where $60 \%$ burned in the following 5 years, decreasing to $29 \%$ for 2006 , and increasing again to $39 \%$ in 2007 . This trend came mainly from grid cells that underwent any kind of conversion. In the grid cells without permanent conversion, the use of fire actually increased somewhat (Fig. 8). 


\section{Discussion}

Multiple lines of evidence demonstrate the successful decrease in deforestation within the BLA under the 2004 Action Plan for the Prevention and Control of Deforestation in the Legal Amazon. This plan introduced innovative procedures for monitoring, environmental control, and territorial management (Assunção et al., 2012). In the same year, the collaboration between INPE and the Center for Environment Monitoring (CEMAM) from the Brazilian Institute of Environment and Renewable Natural Resources (IBAMA) created the System for Detection of Deforested Areas in Real Time (DETER). This new program generated maps of areas with critical forest cover changes in near real-time, which proved to be an important tool for law enforcement (May et al., 2011). In both data sets used in this study, the post2004 drop in tree cover loss and deforestation can be clearly identified. According to GFC, the resulting downward trend is mainly occurring in states within the arc of deforestation. In 2006, the soy moratorium was implemented to prohibit the trade of soybean produced in deforested areas (Meyfroidt and Lambin, 2011). After 5 years of application, Rudorff et al. (2011) concluded that, although it was premature to attribute the decrease in deforestation in the Amazon biome to this moratorium, it had undoubtedly created an inhibitory effect on the expansion of soybean in this biome. After this moratorium, $90 \%$ of the soybean plantation expansion occurred on land previously used as rangeland (Lapola et al., 2010).

In the future, the Brazilian government is willing to significantly increase the production of biofuel (Bergmann et al., 2013). One consequence could be the migration of cattle ranchers to other regions, thereby increasing deforestation (Nepstad et al., 2006). According to GFC, forest cover loss ceased to decrease shortly after the implementation of this moratorium. This study cannot connect these two facts, but one hypothesis could be that more non-primary forest has been cleared to allow the soybean extension or the resettlement of cattle ranchers without breaching the moratorium agreements.

Pará ranked second with regard to forest cover loss and deforestation in 2002, behind Mato Grosso. Mato Grosso drastically reduced its tree clearing rates, and so did Pará, but to a lesser extent. Mato Grosso had only $44 \%$ of its area covered by evergreen broadleaf forest in 2002 compared to $80 \%$ for Pará. The availability of land accessible to clear may explain part of the difference in absolute trend strength. We observed that some regions in Pará that were not substantially impacted by clearing fires early in our study period became hotspots towards the end. For example, in the region of Tucumã in central Pará, fire and clearing were not collocated in 2004 but became very active in 2005, 2007, and 2010. A highly fragmented forest region may potentially explain this, as close access to the Xingu River, a tributary of the Amazon River, facilitates tree removal. Further north in

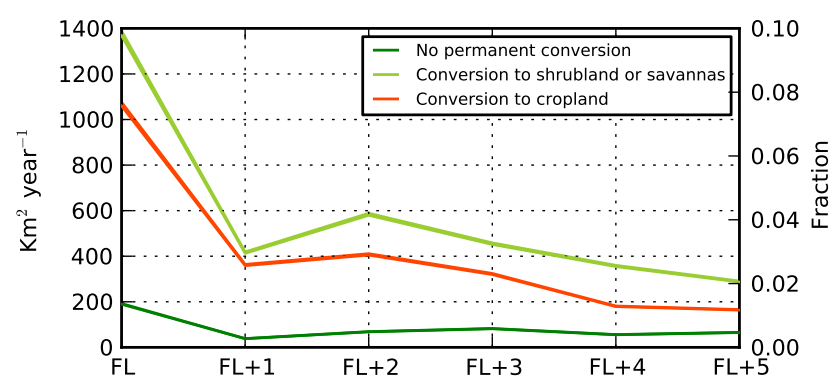

Figure 7. The degree to which fire is used in the deforestation process for different post-forest-loss land cover, shown for the year of forest loss (FL) and 5 years afterwards. Data are averaged for the 6-year periods starting between 2002 and 2007. The right $y$ axis indicates the burned area as a percentage of 2002-2007 averaged evergreen broadleaf forest loss $\left(14211 \mathrm{~km}^{2} \mathrm{year}^{-1}\right)$ and in total sums up to $46 \%$ of total forest loss.

Pará, we noted that strong tree cover loss was occurring without burned area being observed. This could be due to higher annual rainfall, which can limit the use of fire in forest clearing.

During our study period, the BLA faced severe drought years in 2005, 2007, and 2010. According to PRODES, these events did not influence the rate of deforestation, except in 2008, when there was a small increase possibly related to the 2007 drought. GFC shows more sensitivity to droughts. This is most evident in 2010, when there was an increase in forest cover loss compared to the previous year, the first time since 2004. However, also 2005 and 2007 showed less of a decline compared to the previous year in GFC than in PRODES. These dry years had also a significant effect on fire in southern and western states. Maranhão and Tocantins had a very strong burning peak, but this did not influence forest cover loss, probably because savannas are by far the dominant land cover here. On the other hand, Mato Grosso and Pará have also seen elevated burning activity increasing the burning of evergreen broadleaf forest, which could explain part of the GFC plateau towards the end of our study period.

Previous work has shown a strong correlation between deforestation and fire occurrences (Aragão et al., 2008; Chen et al., 2013). Although deforestation and forest cover loss have declined sharply since 2004, burned area did not follow this trend because only a small fraction of burned area is associated with forest cover loss and because droughts have a strong impact on the interannual variability in burned area. Although the effects of droughts are not uniform between all states, general impacts are evident. Burned area always exceeded forest cover loss area due to the fact that fires in grassland and on agricultural grounds are not part of deforestation or forest cover loss. States with a relatively small fraction of evergreen broadleaf forest but a larger portion of cerrado (low tree cover), such as Mato Grosso, Tocantins, and Maranhão, have in general more fire activity in the con- 


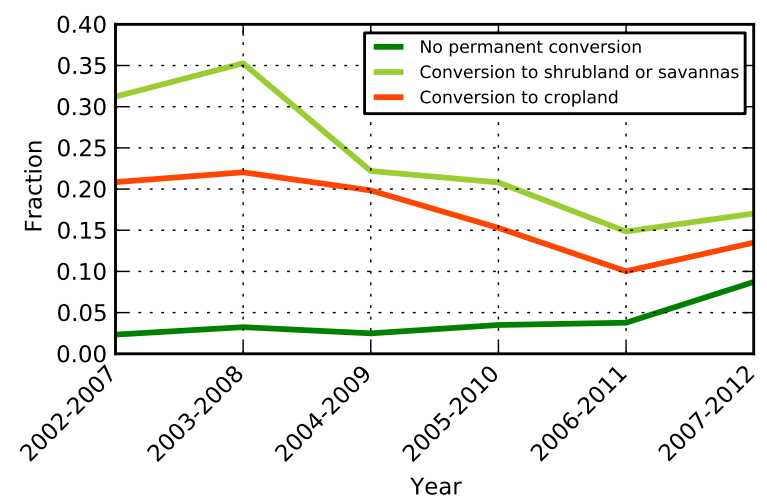

Figure 8. Fraction of forest loss grid cells where burned area is observed in the 5 years following forest loss. Results are shown for three different post-forest-loss land cover types defined as the land cover type observed 5 years after the forest loss event.

version to agriculture or grazing process (Mistry, 1998). In Mato Grosso and Pará, we found that, relatively speaking, less burned area in our low-tree-cover class occurred in pastures compared to non-managed land. This indicates that management in general decreases burned area for this land cover class.

Our results on time intervals between forest cover loss and burned area show that, although large fire years occurred throughout our study period, the overall rate of burned area per unit forest loss is decreasing. In other words, over our study period the post-conversion use of fire decreased. About $54 \%$ of the evergreen broadleaf forest that was cleared in 2002 burned in the following 5 years, dropping to $29 \%$ for the evergreen broadleaf forest cleared in 2006. However, this number was somewhat higher (39\%) in 2007, which was a dry year and the second highest fire year during our study period. Longer time series will enable us to see whether the increase in post-forest-loss fire use in 2007 was a temporary result because of the drought or that the downward trend is increasing again. Lima et al. (2012) showed, in one Landsat 5 TM tile located between Rondônia and Mato Grosso, that $53 \%$ of the 2005 fires occurred in land deforested within the prior 5 years. Aragão and Shimabukuro (2010), however, found that between 2000 and 2007, $59 \%$ of areas experiencing reduction in deforestation rates had an increase in fire events. Using $0.25^{\circ}$ spatial resolution, they explain that this reverse trend could come from secondary forest clearing, which was not detected by PRODES. Our results at $500 \mathrm{~m}$ resolution indicate that, within the same time period (20002007), more than $50 \%$ of the cleared vegetation greater than $5 \mathrm{~m}$ in height was burned within a few years, but this number dropped below $40 \%$ after 2004. This shows that burned area per unit forest loss area decreased after the study period of Aragão and Shimabukuro (2010).

By combining the three different data sets, we have aimed to not only understand the differences between them but also highlight uncertainties associated with relying on one data set. Our study shows that, at least for the Brazilian Amazon, secondary forest loss and fire dynamics outside the primary tropical forest domain may be equally important in regulating atmospheric $\mathrm{CO}_{2}$ concentrations as the much better studied dynamics within the primary forest. The exact impact of these processes requires taking into account the biomass density (e.g., Baccini et al., 2012), which will be the subject of a follow-up study. These types of fires are also important in other regions outside the BLA (e.g., Chen et al., 2013), and expanding the current focus on deforestation regions to also include woodland dynamics may be an important step in better understanding biosphere-atmosphere interactions and biodiversity issues. For example, large-scale carbon budget studies often use deforestation rates in their assessments of sources and sinks of carbon (Le Quéré et al., 2013).

One key uncertainty we have not addressed here is the use of burned area to study fire extent. The burned area algorithms are often geared towards detecting relatively large fires, and not all fires in tree cover loss or deforestation zones may be flagged as burned by them. In addition, it is not well known how reliable the burned area data are in forest loss or deforestation regions. The use of active fires instead of, or in combination with, burned area may mitigate some of these issues (Randerson et al., 2012). However, these approached rely on statistics between active fires and burned area that can only be derived from coarse scale analyses; in the study by Randerson et al. (2012), a $0.25^{\circ}$ spatial resolution was used, which is far too coarse for our purposes. At native resolution, active fires are still 4 times coarser than burned area, but the key issue is that active fires can be associated with both a small agricultural burn and a large fire consuming all biomass in the grid cell. Because of this lack of quantitative information, we refrained from using active fires. In the future, higher-resolution observations from, for example, VIIRS (Schroeder et al., 2014) may enable simultaneous use of burned area and active fires in native-resolution applications like ours.

\section{Conclusions}

We used satellite observation of deforestation (PRODES), forest cover loss (GFC), burned area (MCD64A1), and land cover (MCD12Q1) between 2002 and 2012 in the Brazilian Legal Amazon (BLA) to study relationships between the different data sets. The PRODES data set indicated that deforestation has sharply declined since 2004, something also seen in the GFC forest cover loss data but to a smaller extent. The states with the strongest decline were in the south of the BLA. Most tree cover loss and deforestation occurred on the edge of the Amazon forest, while more burned area was located on the outskirts of the arc of deforestation. Looking at coinciding forest cover loss and burned area, we found variability in the spatial distribution during our study pe- 
riod. This was most predominantly found in the state of Pará, where burned area and forest cover loss were not linked up to 2004, which changed later when large patches of burned area coinciding with forest cover loss were observed in the southwest and the center of the state during the dry years of 2007 and 2010. This indicates that droughts not only enhance burned area but also increase forest cover loss in, for example, secondary forests. These dynamics are not necessarily monitored by PRODES, which excludes grid cells that have been deforested before, but are important to be included in large-scale carbon cycle studies.

Early in our study period, more than $50 \%$ of cleared evergreen broadleaf forest was burned throughout the subsequent 5 years, reducing to below $40 \%$ during the last time segment studied (2007-2012). In other words, besides the welldocumented decrease in deforestation rates, we also showed that burned area per unit forest loss area decreased over our study period. More research is required to better understand these dynamics; one potential reason could be that with lower deforestation rates the previously deforested lands are becoming more intensively managed. This is partly supported by our finding that, in Mato Grosso and Pará, burned area in managed pasture is on average 5 times less frequent than in unmanaged land.

\section{The Supplement related to this article is available online at doi:10.5194/bg-12-6033-2015-supplement.}

Acknowledgements. We acknowledge NASA, INPE, and Matthew Hansen for making their data publicly available, and Douglas Morton for helpful discussions. This research was supported by the European Research Council, grant number 280061 .

Edited by: K. Thonicke

\section{References}

Aragão, L. E. O. C. and Shimabukuro, Y. E.: The Incidence of Fire in Amazonian Forests with Implications for REDD, Science, 328, 1275-1278, doi:10.1126/science.1186925, 2010.

Aragão, L. E. O. C., Malhi, Y., Roman-Cuesta, R. M., Saatchi, S., Anderson, L. O., and Shimabukuro, Y. E.: Spatial patterns and fire response of recent Amazonian droughts, Geophys. Res. Lett., 34, doi:10.1029/2006GL028946, 2007.

Aragão, L. E. O. C., Malhi, Y., Barbier, N., Lima, A., Shimabukuro, Y., Anderson, L., and Saatchi, S.: Interactions between rainfall, deforestation and fires during recent years in the Brazilian Amazonia, Philos. T. R. Soc. B, 363, 1779-1785, doi:10.1098/rstb.2007.0026, 2008.

Assunção, J., Gandour, C. C., and Rocha, R.: Deforestation slowdown in the Legal Amazon: prices or policies, Climate Policy Initiative Working Paper, p. 2, 2012.
Baccini, A., Goetz, S. J., Walker, W. S., Laporte, N. T., Sun, M., Sulla-Menashe, D., Hackler, J., Beck, P. S. A., Dubayah, R., Friedl, M. A., Samanta, S., and Houghton, R. A.: Estimated carbon dioxide emissions from tropical deforestation improved by carbon-density maps, Nature Climate Change, 2, 182-185, 2012.

Balch, J., Nepstad, D., and Curran, L.: Pattern and process: Fireinitiated grass invasion at Amazon transitional forest edges, in: Tropical Fire Ecology, Springer Praxis Books, Springer Berlin Heidelberg, 481-502, 2009.

Bergmann, J. C., Tupinambá, D. D., Costa, O. Y. A., Almeida, J. R. M., Barreto, C. C., and Quirino, B. F.: Biodiesel production in Brazil and alternative biomass feedstocks, Renewable and Sustainable Energy Reviews, 21, 411-420, doi:10.1016/j.rser.2012.12.058, 2013.

Broadbent, E. N., Asner, G. P., Keller, M., Knapp, D. E., Oliveira, P. J. C., and Silva, J. N.: Forest fragmentation and edge effects from deforestation and selective logging in the Brazilian Amazon, Biol. Conserv., 141, 1745-1757, doi:10.1016/j.biocon.2008.04.024, 2008.

Broich, M., Stehman, S. V., Hansen, M. C., Potapov, P., and Shimabukuro, Y. E.: A comparison of sampling designs for estimating deforestation from Landsat imagery: A case study of the Brazilian Legal Amazon, Remote Sens. Environ., 113, 2448 2454, doi:10.1016/j.rse.2009.07.011, 2009.

Carreiras, J. M. B., Pereira, J. M. C., and Shimabukuro, Y. E.: Land-cover Mapping in the Brazilian Amazon Using SPOT-4 Vegetation Data and Machine Learning Classification Methods, Photogramm. Eng. Rem. S., 72, 897-910, doi:10.14358/pers.72.8.897, 2006.

Chen, Y., Randerson, J. T., Morton, D. C., DeFries, R. S., Collatz, G. J., Kasibhatla, P. S., Giglio, L., Jin, Y., and Marlier, M. E.: Forecasting Fire Season Severity in South America Using Sea Surface Temperature Anomalies, Science, 334, 787-791, doi:10.1126/science.1209472, 2011.

Chen, Y., Morton, D. C., Jin, Y., Collatz, G. J., Kasibhatla, P. S., van der Werf, G. R., DeFries, R. S., and Randerson, J. T.: Long-term trends and interannual variability of forest, savanna and agricultural fires in South America, Carbon Management, 4, 617-638, doi:10.4155/cmt.13.61, 2013.

Cochrane, M. A. and Laurance, W. F.: Synergisms among Fire, Land Use, and Climate Change in the Amazon, AMBIO: A Journal of the Human Environment, 37, 522-527, doi:10.1579/00447447-37.7.522, 2008.

de Almeida, C. A., Pinheiro, T. F., Barbosa, A. M., de Abreu, M. R. B. S., de Lucia Lobo, F., Silva, M., Gomes, A. R., Sadeck, L. W. R., de Medeiros, L. T. B., and Neves, M. F.: Metodologia para mapeamento de vegetação secundária na Amazônia Legal, INPE-16621-RPQ/839, 2009.

Fearnside, P. M.: Deforestation in Brazilian Amazonia: History, Rates, and Consequences, Conserv. Biol., 19, 680-688, doi:10.1111/j.1523-1739.2005.00697.x, 2005.

Fearnside, P. M., Righi, C. A., Graça, P. M. L. d. A., Keizer, E. W. H., Cerri, C. C., Nogueira, E. M., and Barbosa, R. I.: Biomass and greenhouse-gas emissions from land-use change in Brazil's Amazonian "arc of deforestation": The states of Mato Grosso and Rondônia, Forest Ecol. Manag., 258, 1968-1978, doi:10.1016/j.foreco.2009.07.042, 2009.

Friedl, M. A., Sulla-Menashe, D., Tan, B., Schneider, A., Ramankutty, N., Sibley, A., and Huang, X.: MODIS Collection 
5 global land cover: Algorithm refinements and characterization of new datasets, Remote Sens. Environ., 114, 168-182, doi:10.1016/j.rse.2009.08.016, 2010.

Giglio, L., Descloitres, J., Justice, C. O., and Kaufman, Y. J.: An Enhanced Contextual Fire Detection Algorithm for MODIS, Remote Sens. Environ., 87, 273-282, doi:10.1016/S00344257(03)00184-6, 2003.

Giglio, L., Loboda, T., Roy, D. P., Quayle, B., and Justice, C. O.: An active-fire based burned area mapping algorithm for the MODIS sensor, Remote Sens. Environ., 113, 408-420, doi:10.1016/j.rse.2008.10.006, 2009.

Hansen, M. C., Shimabukuro, Y. E., Potapov, P., and Pittman, K.: Comparing annual MODIS and PRODES forest cover change data for advancing monitoring of Brazilian forest cover, Remote Sens. Environ., 112, 3784-3793, doi:10.1016/j.rse.2008.05.012, 2008.

Hansen, M. C., Potapov, P. V., Moore, R., Hancher, M., Turubanova, S. A., Tyukavina, A., Thau, D., Stehman, S. V., Goetz, S. J., Loveland, T. R., Kommareddy, A., Egorov, A., Chini, L., Justice, C. O., and Townshend, J. R. G.: High-Resolution Global Maps of 21st-Century Forest Cover Change, Science, 342, 850-853, doi:10.1126/science.1244693, 2013.

Holdsworth, A. R. and Uhl, C.: Fire in Amazonian selectively logged rain forest and the potential for fire reduction, Ecol. Appl., 7, 713-725, doi:10.1890/10510761(1997)007[0713:fiaslr]2.0.co;2, 1997.

INPE: http://www.obt.inpe.br/prodes/prodes_1988_2013.htm (last access: 18 March 2015), 2014.

IPCC: Climate change 2007: the physical science basis. In: Contribution of Working Group I to the Fourth Assessment Report of the Intergovernmental Panel on Climate Change, edited by: Solomon S., Qin, D., Manning, M., Chen, Z., Marquis, M., Averyt, K. B., Tignor, M., and Miller, H. L., Cambridge University Press 2007 Cambridge, UK and New York, NY, USA, 996 pp., 2007.

Johns, J. S., Barreto, P., and Uhl, C.: Logging damage during planned and unplanned logging operations in the eastern Amazon, Forest Ecol. Manag., 89, 59-77, doi:10.1016/S03781127(96)03869-8, 1996.

Kirby, K. R., Laurance, W. F., Albernaz, A. K., Schroth, G., Fearnside, P. M., Bergen, S., Venticinque, E. M., and da Costa, C.: The future of deforestation in the Brazilian Amazon, Futures, 38, 432-453, doi:10.1016/j.futures.2005.07.011, 2006.

Lapola, D. M., Schaldach, R., Alcamo, J., Bondeau, A., Koch, J., Koelking, C., and Priess, J. A.: Indirect land-use changes can overcome carbon savings from biofuels in Brazil, P. Natl. Acad. Sci. USA, 107, 3388-3393, doi:10.1073/pnas.0907318107, 2010.

Le Quéré, C., Andres, R. J., Boden, T., Conway, T., Houghton, R. A., House, J. I., Marland, G., Peters, G. P., van der Werf, G. R., Ahlström, A., Andrew, R. M., Bopp, L., Canadell, J. G., Ciais, P., Doney, S. C., Enright, C., Friedlingstein, P., Huntingford, C., Jain, A. K., Jourdain, C., Kato, E., Keeling, R. F., Klein Goldewijk, K., Levis, S., Levy, P., Lomas, M., Poulter, B., Raupach, M. R., Schwinger, J., Sitch, S., Stocker, B. D., Viovy, N., Zaehle, S., and Zeng, N.: The global carbon budget 1959-2011, Earth Syst. Sci. Data, 5, 165-185, doi:10.5194/essd-5-165-2013, 2013.
Lewis, S. L., Brando, P. M., Phillips, O. L., van der Heijden, G. M. F., and Nepstad, D.: The 2010 Amazon Drought, Science, 331, 554 pp., doi:10.1126/science.1200807, 2011.

Lima, A., Silva, T. S. F., Aragão, L. E. O. E. C. D., Feitas, R. M.D., Adami, M., Formaggio, A. R., and Shimabukuro, Y. E.: Land use and land cover changes determine the spatial relationship between fire and deforestation in the Brazilian Amazon, Appl. Geogr., 34, 239-246, doi:10.1016/j.apgeog.2011.10.013, 2012.

Loveland, T. R. and Belward, A. S.: The IGBP-DIS global $1 \mathrm{~km}$ land cover data set, DISCover: First results, Int. J. Remote Sens., 18, 3289-3295, doi:10.1080/014311697217099, 1997.

Malhi, Y., Aragão, L. E. O. C., Galbraith, D., Huntingford, C., Fisher, R., Zelazowski, P., Sitch, S., McSweeney, C., and Meir, P.: Exploring the likelihood and mechanism of a climate-changeinduced dieback of the Amazon rainforest, P. Natl. Acad. Sci. USA, 106, 20610-20615, doi:10.1073/pnas.0804619106, 2009.

Marengo, J. A., Nobre, C. A., Tomasella, J., Oyama, M. D., Sampaio de Oliveira, G., de Oliveira, R., Camargo, H., Alves, L. M., and Brown, I. F.: The Drought of Amazonia in 2005, J. Climate, 21, 495-516, doi:10.1175/2007jcli1600.1, 2008.

May, P. H., Millikan, B., and Gebara, M. F.: The context of REDD+ in Brazil: Drivers, agents and institutions, CIFOR, p. 59, doi:10.17528/cifor/003287, 2011.

Meyfroidt, P. and Lambin, E. F.: Global Forest Transition: Prospects for an End to Deforestation, Annu. Rev. Environ. Resour., 36, 343-371, doi:10.1146/annurev-environ-090710-143732, 2011.

Mistry, J.: Fire in the cerrado (savannas) of Brazil: an ecological review, Prog. Phys. Geogr., 22, 425-448, doi:10.1177/030913339802200401, 1998.

Morton, D. C., DeFries, R. S., Shimabukuro, Y. E., Anderson, L. O., Del Bon Espírito-Santo, F., Hansen, M., and Carroll, M.: Rapid Assessment of Annual Deforestation in the Brazilian Amazon Using MODIS Data, Earth Interact., 9, 1-22, doi:10.1175/EI139.1, 2005.

Morton, D. C., DeFries, R. S., Shimabukuro, Y. E., Anderson, L. O., Arai, E., del Bon Espirito-Santo, F., Freitas, R., and Morisette, J.: Cropland expansion changes deforestation dynamics in the southern Brazilian Amazon, P. Natl. Acad. Sci. USA, 103, 14637-14641, doi:10.1073/pnas.0606377103, 2006.

Morton, D. C., Defries, R. S., Randerson, J. T., Giglio, L., Schroeder, W., and Van Der Werf, G. R.: Agricultural intensification increases deforestation fire activity in Amazonia, Glob. Change Biol., 14, 2262-2275, doi:10.1111/j.13652486.2008.01652.x, 2008.

Nepstad, D., Carvalho, G., Cristina Barros, A., Alencar, A., Paulo Capobianco, J., Bishop, J., Moutinho, P., Lefebvre, P., Lopes Silva Jr, U., and Prins, E.: Road paving, fire regime feedbacks, and the future of Amazon forests, Forest Ecol. Manag., 154, 395407, doi:10.1016/S0378-1127(01)00511-4, 2001.

Nepstad, D. C., de Carvalho, C. R., Davidson, E. A., Jipp, P. H., Lefebvre, P. A., Negreiros, G. H., da Silva, E. D., Stone, T. A., Trumbore, S. E., and Vieira, S.: The role of deep roots in the hydrological and carbon cycles of Amazonian forests and pastures, Nature, 372, 666-669, doi:10.1038/372666a0, 1994.

Nepstad, D. C., Stickler, C. M., and Almeida, O. T.: Globalization of the Amazon Soy and Beef Industries: Opportunities for Conservation, Conserv. Biol., 20, 1595-1603, doi:10.1111/j.15231739.2006.00510.x, 2006. 
Nobre, C. A., Sellers, P. J., and Shukla, J.: Amazonian Deforestation and Regional Climate Change, J. Climate, 4, 957988, doi:10.1175/1520-0442(1991)004<0957:adarcc> 2.0.co;2, 1991.

Osborne, P.: Tropical Ecosystems and Ecological Concepts, edited by: Press, C. U., Cambridge, UK, 2000.

Randerson, J. T., Chen, Y., van der Werf, G. R., Rogers, B. M., and Morton, D. C.: Global burned area and biomass burning emissions from small fires, J. Geophys. Res.-Biogeo., 117, G04012, doi:10.1029/2012jg002128, 2012.

Roy, D. P., Boschetti, L., Justice, C. O., and Ju, J.: The collection 5 MODIS burned area product - Global evaluation by comparison with the MODIS active fire product, Remote Sens. Environ., 112, 3690-3707, doi:10.1016/j.rse.2008.05.013, 2008.

Rudorff, B. F. T., Adami, M., Aguiar, D. A., Moreira, M. A., Mello, M. P., Fabiani, L., Amaral, D. F., and Pires, B. M.: The Soy Moratorium in the Amazon Biome Monitored by Remote Sensing Images, Remote Sens., 3, 185-202, doi:10.3390/rs3010185, 2011.

Schroeder, W., Oliva, P., Giglio, L., and Csiszar, I. A.: The New VIIRS $375 \mathrm{~m}$ active fire detection data product: Algorithm description and initial assessment, Remote Sens. Environ., 143, 85-96, doi:10.1016/j.rse.2013.12.008, 2014.

Shimabukuro, Y. E., Batista, G. T., Mello, E. M. K., Moreira, J. C., and Duarte, V.: Using shade fraction image segmentation to evaluate deforestation in Landsat Thematic Mapper images of the Amazon Region, Int. J. Remote Sens., 19, 535-541, doi:10.1080/014311698216152, 1998.
Tinker, P. B., Ingram, J. S. I., and Struwe, S.: Effects of slash-and-burn agriculture and deforestation on climate change, Agriculture, Ecosys. Environ., 58, 13-22, doi:10.1016/01678809(95)00651-6, 1996.

Tucker, C. J., Grant, D. M., and Dykstra, J. D.: NASA's Global Orthorectified Landsat Data Set, Photogramm. Eng. Rem. S., 70, 313-322, doi:10.14358/pers.70.3.313, 2004.

Valeriano, D. M., Mello, E. M. K., Moreira, J. C., Shimabukuro, Y. E., and Duarte, V.: Monitoring tropical forest from space: the PRODES digital project, Int. Arch. Photogramm. Remote Sens. Spatial Inf. Sci., 35, 272-274, 2004.

van der Werf, G. R., Dempewolf, J., Trigg, S. N., Randerson, J. T., Kasibhatla, P. S., Giglio, L., Murdiyarso, D., Peters, W., Morton, D. C., Collatz, G. J., Dolman, A. J., and DeFries, R. S.: Climate regulation of fire emissions and deforestation in equatorial Asia, P. Natl. Acad. Sci. USA, 105, 20350-20355, doi:10.1073/pnas.0803375105, 2008.

van der Werf, G. R., Morton, D. C., DeFries, R. S., Giglio, L., Randerson, J. T., Collatz, G. J., and Kasibhatla, P. S.: Estimates of fire emissions from an active deforestation region in the southern Amazon based on satellite data and biogeochemical modelling, Biogeosciences, 6, 235-249, doi:10.5194/bg-6-235-2009, 2009.

Van Nieuwstadt, M. G. L., Sheil, D., and Kartawinata, K.: The Ecological Consequences of Logging in the Burned Forests of East Kalimantan, Indonesia, Conserv. Biol., 15, 1183-1186, doi:10.1046/j.1523-1739.2001.0150041183.x, 2001. 